\title{
Effect of Seed Hardening and Irrigation on Growth and Yield of Wheat (Triticum aestivum L.)
}

\author{
Tabom Tatak*, Rajesh Singh and Punnam Chhetri
}

Department of Agronomy, Sam Higginbottom University of Agriculture, Technology and Sciences, Prayagraj, Uttar Pradesh India

*Corresponding author

\section{A B S T R A C T}

\begin{tabular}{|l|}
\hline Key w or d s \\
Wheat, PEG, $\mathrm{GA}_{3}$, \\
Irrigation \\
\hline Article Info \\
\hline $\begin{array}{l}\text { Accepted: } \\
\text { 14 January } 2021 \\
\text { Available Online: } \\
\text { 10 February } 2021\end{array}$ \\
\hline
\end{tabular}

The experiment was conducted at the Crop Research Farm, Department of Agronomy, Naini Agricultural Institute, Sam Higginbottom University of Agriculture, Technology and

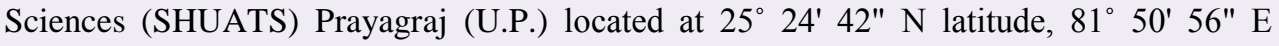
longitude and at an altitude of $98 \mathrm{~m}$ above mean sea level during the rabi season 20192020 to evaluate the performance of various seed hardening chemicals viz. Distilled water, $\mathrm{KNO}_{3}$ at $1000 \mathrm{mg} / \mathrm{l}$, PEG at $15 \%$ and $\mathrm{GA}_{3}$ at $450 \mathrm{mg} / \mathrm{lin}$ late sown variety of wheat (Triticumaestivum L.).The plant height was highest in $\mathrm{GA}_{3}$ at $450 \mathrm{mg} / \mathrm{l}+$ Three Irrigations at crown root initiation, jointing and anthesis $(81.27 \mathrm{~cm})$, the maximum dry weight was noted in PEG at $15 \%+$ Three Irrigations at crown root initiation, jointing and anthesis stage $(24.00 \mathrm{~g})$. The no. of total effective tillers $/ \mathrm{m}^{2}(402)$, straw yield $(45.15 \mathrm{t})$, grain yield $(3.52 \mathrm{t})$ and harvest index (5.82) was observed in the treatment PEG at 15\%+Three Irrigations at crown root initiation, jointing and anthesis stage.

\section{Introduction}

In India wheat crop is cultivated in rabi season. It is normally sown during November and harvested between March and April. The cultivated area under wheat at national level has shown increasing trend, from 29.04 million hectare to 30.54 million hectare with a magnitude of 1.5 million hectare $(5 \%)$ net gain in terms of area. Uttar Pradesh has largest share in area with 9.75 million hectare $(32 \%)$.

The production of wheat has also showed an increasing trend, from 87.39 to 94.57 million tons from 2012-2013 to 2017-2018 with a magnitude of 7.18 million tonnes $(8.22 \%)$. However, in the past decade a general slowdown in increase in the productivity of wheat has been noticed (Nagarajan, 2005).

In rice-wheat systems, late sowing of wheat is also one of the major reason of low yield. This yield reduction is principally due to lower and erratic germination, and poor crop establishment because of low temperature prevailing. Good crop establishment is one of the major challenges to crop production and its importance is recognized by farmers as well as researchers (Chivasa et al., 1998). 
Seed hardening has been found a doable technology to enhance rapid and uniform emergence, high vigor, and better yields in field crops (Dearman et al., 1987). Seed priming has been commonly employed to reduce the time between seed sowing and seedling emergence and the synchronization of emergence (Parera and Cantliffe,1994).

Priming of wheat seed in water has been observed to improve the germination and emergence (Ashraf and Abu-Shakra, 1978) and promote vigorous root growth (Carceller and Soriano, 1972).under low soil water potential compared with untreated seeds. The rationale is that sowing soaked seed decreases the time needed for germination and may allow the seedling to escape deteriorating soil physical conditions. It had resulted in more germination speed especially in drought stress and low temperatures in various crops (Sivritepe et al., 2003). Seed priming allows some of the metabolic processes necessary for germination to occur without germination taking place. Treating the seed with chemicals or growth hormones like GA3 treatment, enhanced the vegetative growth by enhancing the deposition of $\mathrm{Na}+$ and $\mathrm{Cl}-$ in both root and shoots. And also cause a significant increase in photosynthetic activity at the vegetative stage of the crops.

The hardening of the seeds or seed treatment with $\mathrm{KNO}_{3}$ solution increases yield, fruit size and improves quality in field and vegetables crops. Priming with $\mathrm{KNO}_{3}$ also results in enhancement of seed germination, mineral composition, proline, $\beta$-amylase and protein.

It has been observed that germination and seedling establishment of some cereals under drought, cold stress, and high salinity were improved following seed Osmo - priming with PEG.A seed hardened with PEG treatment indicated a relationship between the pattern of water absorption, the reactivation of mitotic activity and the start and synchronization of germination. Thus, enhancing a better germination compared to the untreated seeds.

Therefore, the present experiment was carried out by keeping this in view, experiment was laid to evaluate "the effect of Seed Hardening and Irrigation on Economics of Wheat (Triticum aestivum L.)."

\section{Materials and Methods}

The experiment was conducted at the Crop Research Farm, Department of Agronomy, Naini Agricultural Institute, Sam Higginbottom University of Agriculture, Technology and Sciences (SHUATS), Prayagraj, Uttar Pradesh which is located at $25^{\circ} 24^{\prime} 42^{\prime \prime} \mathrm{N}$ latitude, $81^{\circ} 50^{\prime} 56^{\prime \prime}$ E longitude and at an altitude of $98 \mathrm{~m}$ above mean sea level. The experiment was conducted during the Rabi season 2019-2020. The experimental soil was sandy loam, with $\mathrm{pH}$ 7.2, Organic C (\%) 0.49 , low in available $\mathrm{N}(109.01 \mathrm{~kg} / \mathrm{ha})$ and medium in available $\mathrm{P}(21.80 \mathrm{~kg} / \mathrm{ha})$ and $\mathrm{K}(270.02 \mathrm{~kg} / \mathrm{ha})$.

The experiment was laid out in a randomized block design, having 13 treatment combinations in 3 replicates. The treatments comprised of $\mathrm{T}_{1}$-Distilled water + One Irrigation at crown root initiation stage, $\mathrm{T}_{2}$ Distilled water + Two Irrigations at crown root initiation and jointing stage, $\mathrm{T}_{3}$-Distilled water + Three Irrigations at crown root initiation, jointing and anthesis stage, $\mathrm{T}_{4}$ $\mathrm{KNO}_{3}$ at $1000 \mathrm{mg} / \mathrm{l}+$ One Irrigation at crown root initiation stage, $\mathrm{T}_{5}-\mathrm{KNO}_{3}$ at $1000 \mathrm{mg} / \mathrm{l}+$ Two Irrigations at crown root initiation and jointing stage, $\mathrm{T}_{6}-\mathrm{KNO}_{3}$ at $1000 \mathrm{mg} / \mathrm{l}+$ Three Irrigations at crown root initiation, jointing and anthesis stage, $\mathrm{T}_{7}$-PEG at $15 \%+$ One Irrigation at crown root initiation stage, $\mathrm{T}_{8}-$ PEG at $15 \%+$ Two Irrigations at crown root initiation and jointing stage, $\mathrm{T}_{9}-\mathrm{PEG}$ at $15 \%$ 
+ Three Irrigations at crown root initiation, jointing and anthesis stage, $\mathrm{T}_{10}-\mathrm{GA}_{3}$ at 450 $\mathrm{mg} / \mathrm{l}+$ One Irrigation at crown root initiation stage, $\mathrm{T}_{11}-\mathrm{GA}_{3}$ at $450 \mathrm{mg} / \mathrm{l}+\mathrm{Two}$ Irrigations at crown root initiation and jointing stage, $\mathrm{T}_{12}$ $-\mathrm{GA}_{3}$ at $450 \mathrm{mg} / \mathrm{l}+$ Three Irrigations at crown root initiation, jointing and anthesis stage, $\mathrm{T}_{13}$ -Control (no seed treatment).

The seeds were soaked in different seed hardening chemicals for 12-14 hours and then dried using tissue papers to remove the excess moisture outside the seed coat. The sizes of each experimental plot were $4 \mathrm{~m} \times 3 \mathrm{~m}$. The wheat variety used in the experiment was Halna (K-7903).

The seeds were sown by line sowing method with spacing of $22.5 \mathrm{~cm}$ manually with the seed rate of $125 \mathrm{~kg} / \mathrm{ha}$. N, P and $\mathrm{K}$ were applied at the rate of 120,60 and $60 \mathrm{~kg}$ per ha, respectively. $\mathrm{N}$ was applied in split application, $50 \%$ at basal and $50 \%$ as top dressing, whereas $\mathrm{P}$ and $\mathrm{K}$ were applied as basal dose.

\section{Results and Discussion}

\section{Growth and yield attributes}

The Maximum plant height $(81.67 \mathrm{~cm})$ was recorded in treatment $T_{12}(\mathrm{GA} 3$ at $450 \mathrm{mg} / \mathrm{l}+$ Three irrigations). Whereas, $\mathrm{T}_{1}$ (Distilled water + One Irrigation), $T_{2}$ (Distilled water + Two irrigations), $\mathrm{T}_{3}$ (Distilled water + Three irrigations), $\mathrm{T}_{6}\left(\mathrm{KNO}_{3}\right.$ at $1000 \mathrm{mg} / \mathrm{l}+$ Three irrigations), $\mathrm{T}_{8}$ (PEG at $15 \%+$ Two irrigations), $\quad \mathrm{T}_{9}$ (PEG at $15 \%+$ Three Irrigations), $\mathrm{T}_{11}\left(\mathrm{GA}_{3}\right.$ at $450 \mathrm{mg} / \mathrm{l}+\mathrm{Two}$ Irrigations), $\mathrm{T}_{13}$ (Control) were at par with $\mathrm{T}_{12}$ $\left(\mathrm{GA}_{3}\right.$ at $450 \mathrm{mg} / \mathrm{l}+$ Three irrigations). The hardening could not affect the plant height much because the standing crops were not given any additional treatments but considering $\mathrm{GA}_{3}$ is a plant growth hormone; its effect on promoting growth is slight. Positive effects of $\mathrm{GA}_{3}$ treatment effects reported include breaking seed dormancy, promoting germination, increasing inter-node length, increasing plant height and encouraging cell division (Ghodrat and Rousta, 2012).

Table.1 Effect of seed hardening and irrigation on growth and yield attributes of wheat

\begin{tabular}{|c|c|c|c|c|}
\hline & Treatments & Plant height (cm) & Dry weight (g) & No. of Total effective tillers $/ \mathrm{m}^{2}$ \\
\hline $\mathrm{T}_{1}:$ & Distilled water +1 irrigation & 78.88 & 18.40 & 247.00 \\
\hline $\mathbf{T}_{2}:$ & Distilled water +2 irrigation & 79.10 & 17.86 & 247.66 \\
\hline T3: & Distilled water +3 irrigation & 81.46 & 19.80 & 330.33 \\
\hline $\mathbf{T}_{4}:$ & $\mathrm{KNO3}$ at $1000 \mathrm{mg} / \mathrm{l}+1$ irrigation & 75.72 & 18.80 & 284.33 \\
\hline $\mathbf{T}_{5}:$ & $\mathrm{KNO3}$ at $1000 \mathrm{mg} / \mathrm{l}+2$ irrigation & 76.02 & 19.53 & 285.00 \\
\hline$T_{6}:$ & $\mathrm{KNO3}$ at $1000 \mathrm{mg} / \mathrm{l}+3$ irrigation & 80.76 & 22.06 & 292.00 \\
\hline $\mathbf{T}_{7}:$ & PEG at $15 \%+1$ irrigation & 79.46 & 18.66 & 302.00 \\
\hline $\mathbf{T}_{8}:$ & PEG at $15 \%+2$ irrigation & 79.80 & 22.20 & 342.00 \\
\hline $\mathbf{T}_{\mathbf{9}}:$ & PEG at $15 \%+3$ irrigation & 80.26 & 24.00 & 402.00 \\
\hline$T_{10}:$ & GA3 at $450 \mathrm{mg} / \mathrm{l}+1$ irrigation & 77.93 & 18.00 & 281.66 \\
\hline $\mathbf{T}_{11}:$ & GA3 at $450 \mathrm{mg} / \mathrm{l}+2$ irrigation & 80.13 & 19.80 & 306.00 \\
\hline$T_{12}:$ & GA3 at $450 \mathrm{mg} / \mathrm{l}+3$ irrigation & 81.67 & 23.80 & 373.00 \\
\hline \multirow[t]{4}{*}{$T_{13}:$} & Control (no seed treatment) & 79.56 & 19.46 & 293.00 \\
\hline & F- Test & $\mathrm{S}$ & S & S \\
\hline & Sem & 1.09 & 0.54 & 27.89 \\
\hline & C.D(0.05) & 3.20 & 1.58 & 81.82 \\
\hline
\end{tabular}

Note: 1 irrigation at CRI stage

2 irrigationsat $\mathrm{CRI}$ and jointing stage

3 irrigations at CRI stage, jointing stage, anthesis stage 
Table.2 Effect of Seed Hardening and Irrigation on Yield attributing characters of wheat

\begin{tabular}{|c|c|c|c|c|}
\hline & Treatments & $\begin{array}{c}\text { Grain } \\
\text { Yield(t/ha) }\end{array}$ & $\begin{array}{c}\text { Straw } \\
\text { Yield(t/ha) }\end{array}$ & Harvest Index $(\%)$ \\
\hline $\mathbf{T}_{1}:$ & Distilled water +1 irrigation & 1.76 & 36.04 & 4.74 \\
\hline $\mathbf{T}_{2}:$ & Distilled water +2 irrigation & 2.41 & 41.50 & 5.50 \\
\hline T3: & Distilled water +3 irrigation & 3.04 & 42.19 & 6.74 \\
\hline $\mathbf{T}_{4}:$ & KNO3 at $1000 \mathrm{mg} / \mathrm{l}+1$ irrigation & 2.05 & 37.75 & 5.17 \\
\hline$T_{5}:$ & $\mathrm{KNO3}$ at $1000 \mathrm{mg} / \mathrm{l}+2$ irrigation & 3.18 & 43.04 & 6.88 \\
\hline$T_{6}:$ & KNO3 at $1000 \mathrm{mg} / \mathrm{l}+3$ irrigation & 3.26 & 43.49 & 6.98 \\
\hline $\mathbf{T}_{7}:$ & PEG at $15 \%+1$ irrigation & 2.03 & 42.86 & 4.52 \\
\hline $\mathbf{T}_{8}:$ & PEG at $15 \%+2$ irrigation & 3.10 & 42.94 & 6.73 \\
\hline $\mathbf{T}_{\mathbf{9}}:$ & PEG at $15 \%+3$ irrigation & 3.52 & 45.15 & 7.27 \\
\hline$T_{10}:$ & GA3 at $450 \mathrm{mg} / \mathrm{l}+1$ irrigation & 1.92 & 41.17 & 4.49 \\
\hline$T_{11}:$ & GA3 at $450 \mathrm{mg} / \mathrm{l}+2$ irrigation & 2.16 & 43.64 & 4.73 \\
\hline $\mathbf{T}_{12}:$ & GA3 at $450 \mathrm{mg} / \mathrm{l}+3$ irrigation & 2.16 & 43.8 & 4.72 \\
\hline \multirow[t]{4}{*}{$\mathbf{T}_{13}:$} & Control (no seed treatment) & 2.23 & 43.69 & 4.85 \\
\hline & F- Test & $\mathrm{S}$ & $\mathrm{S}$ & $\mathrm{S}$ \\
\hline & Sem & 0.25 & 1.20 & 0.59 \\
\hline & C.D(0.05) & 0.74 & 3.53 & 1.74 \\
\hline
\end{tabular}

Note: $* 1$ irrigation at CRI stage

$* 2$ irrigations at CRI and jointing stage

*3 irrigations at CRI stage, jointing stage, anthesis stage

\section{Dry matter accumulation}

A linear increase in Dry matter accumulation was observed from tillering to harvest. The dry matter accumulation (24.00g) was significantly superior in treatment $\mathrm{T}_{9}$ (PEG at $15 \%+$ Three irrigations) and treatment $\mathrm{T}_{12}$ $\left(\mathrm{GA}_{3}\right.$ at $450 \mathrm{mg} / \mathrm{l}+$ Three irrigations) was found to be statistically at par with the highest. Priming presumably permitted some repairs to damaged membrane caused by deterioration and exerted better germination pattern and higher vigor level than nonprimed (Ruan et al., 2004). The cause of rapid increase of Dry matter accumulation at crop harvest was possibly due to emergence of number of new tillers/plantand more fertile spikes/plant (Alam, 2013).

\section{Effective tillers per $\mathbf{m}^{2}$}

Maximum no. of total effective tillers per $\mathrm{m}^{2}(402)$ were found with application of $T_{9}$
(PEG at $15 \%+3$ irrigations), whereas, $\mathrm{T}_{3}$ (Distilled water + Three Irrigations), $\mathrm{T}_{7}$ (PEG at $15 \%+$ One Irrigations), $\mathrm{T}_{12}$ (GA3 at 450 $\mathrm{mg} / \mathrm{l}+$ Three irrigation) were found statistically at par with the highest treatment. These results were in conformity with the results of Rohool et al., (2016) who also observed that the Seed hardening for 24 hours with PEG-8000 significantly increases various growth characters viz., plant height, number of effective tillers and yield attributes in Wheat.

\section{Yield (kg/ha)}

Maximum grain yield (3.52t) was recorded in the treatment $\mathrm{T}_{9}(\mathrm{PEG}$ at $15 \%+$ Three irrigations), whereas $\mathrm{T}_{3}$ (Distilled water + Three Irrigations), $\mathrm{T}_{5}\left(\mathrm{KNO}_{3}\right.$ at $1000 \mathrm{mg} / \mathrm{l}+$ Two Irrigations), $\mathrm{T}_{6}\left(\mathrm{KNO}_{3}\right.$ at $1000 \mathrm{mg} / \mathrm{l}+$ Three Irrigations) and $\mathrm{T}_{8}$ (PEG at $15 \%+\mathrm{Two}$ Irrigations)were found to be statistically at par with the highest. The increase in the yield by 
seed hardening with PEG and $\mathrm{KNO}_{3}$ may be due to improvement in yield components mainly seed yield/plant and harvest index. These results are in agreement with Manjunath and Dhanoji, (2011) who stated that treating wheat seeds with PEG and $\mathrm{KNO}_{3}$ increased the grain yield compare to control. Haris et al., (1999) observed 15\% increase in grain yield by seed hardening and stated that success of hardening techniques depends on type of cultivar, osmotic potential solution, temperature, seed vigor, rate of seed re-drying and conditions during seed storage.

\section{Straw yield}

Maximum Straw yield (45.15t) were was found to be significantly higher with the treatment $\mathrm{T}_{9}(\mathrm{PEG}$ at $15 \%$ + Three irrigations $)$, whereas $\mathrm{T}_{3}$ (Distilled water+ Three irrigations $), \mathrm{T}_{5}\left(\mathrm{KNO}_{3}\right.$ at $1000 \mathrm{mg} / \mathrm{l}+\mathrm{Two}$ irrigations), $\mathrm{T}_{6}\left(\mathrm{KNO}_{3}\right.$ at $1000 \mathrm{mg} / \mathrm{l}+$ Three irrigations $), \mathrm{T}_{7}(\mathrm{PEG}$ at $15 \%+$ one irrigation at CRI stage), $\mathrm{T}_{8}$ (PEG at $15 \%+$ Two irrigations), $\mathrm{T}_{11}\left(\mathrm{GA}_{3}\right.$ at $450 \mathrm{mg} / \mathrm{l}+\mathrm{Two}$ irrigations), $\mathrm{T}_{12}$ $\left(\mathrm{GA}_{3}\right.$ at $\left.450 \mathrm{mg} / \mathrm{l}\right), \mathrm{T}_{13}$ (Control)were found to be statistically at par with the highest.

The increase in straw yield with pre sowing treatment was due to the expansion of leaves, which resulted in higher photosynthesis, assimilation and ultimately higher production of total dry matter. Misra and Dwibedi, (1980) reported $37 \%$ increase in yield of wheat due to pre-sowing techniques.

\section{Harvest index}

Highest percentage of harvest index (7.27) was observed in the treatment $\mathrm{T}_{9}$ (PEG at $15 \%$ + Three irrigations), whereas $\mathrm{T}_{3}$ (Distilled water+ Three irrigations), $\mathrm{T}_{5}\left(\mathrm{KNO}_{3}\right.$ at 1000 $\mathrm{mg} / \mathrm{l}+$ Two irrigations $), \mathrm{T}_{6}\left(\mathrm{KNO}_{3}\right.$ at 1000 $\mathrm{mg} / \mathrm{l}+$ Three irrigations) and $\mathrm{T}_{8}$ (PEG at $15 \%+$ Two irrigations)were found to be statistically at par with the highest. The improvement in harvest index due to priming could be attributed to better emergence and crop yields caused by seed priming (Minhas et al., 1995).

It can be concluded that PEG at $15 \%+$ three irrigations $\left(\mathrm{T}_{9}\right)$, which recorded significantly higher growth and yield parameters performed better than the remaining treatments. Hence, it can be recommended to the farmers.

\section{References}

Ahsan H., Tariq H. M. M. and Hossain A.(2017), Polyethylene Glycol (PEG) Induced Changes in Germination, Seedling Growth and Water Relation Behavior of Wheat (Triticum aestivum L.) Genotypes. Universal Journal of Plant Science, 2017; 5(4): 49-57.

Amin R and Khan A.Z (2016) Influence of Seed Hardening Techniques on Vigor, Growth and Yield of Wheat under Drought Conditions. Journal of Agricultural Studies,2016, Vol. 4, No. 3 121-131.

Bassi, G. (2005). Seed priming for invigourating late sown wheat (Triticum aestivum).Crop Improv.2005: 32: 12123.

Farooq M., Basra S. M.A and Rehman M. (2008) Seed Priming Enhances the Performance of Late SownWheat (Triticum aestivum L.) by Improving Chilling Tolerance.J. Agronomy \& Crop Science, 2008; 194; 55-60.

Harmeet Singh H., Jassal R.K. and Kang J.S. (2015), Seed priming techniques in field crops - A review. Agri. Review, 36 (4) 2015: 251-264.

Hong Y.M and Zhao D.D (2018) A Multiyear Beneficial Effect of Seed Priming with Gibberellic Acid-3 (GA3) on Plant Growth and Production in a Perennial Grass. Scientific Reports, 2018; 8:13- 
14.

Jalilian J., R. Khalilzadeh and E. Khanpaye, "Improving of barley seedling growth by seed priming under water deficit stress".J stress physiol and Biochem vol. 10, no. 2, pp. 125-134, 2014.

Khonok, A., Gohari, A. A., Dargah, R.E., Effect of irrigation management and straw Mulch on yield of common bean (Phaseolus vulgaris L.).AmericanEurasian Journal of Agronomy, 2012; 5: 40-43.

Mabhaudhi, T. and Modi, A. T. (2011). Can hydro-priming improve germination speed, vigour and emergence of maizelandraces under water stress? $J$ AgriSci Tech Bio.2011:1:20-28.

Mishra, N. M. and Dwibedi, D. P. (1980).Effect of pre sowing seed treatment on growth and dry matter accumulation ofhigh yielding wheat under rainfed condition. Indian Journal Agron.25: 230-34.

Robin A.K.H, Jasiman M.U. and Khandaker N.B. () Polyethylene Glycol (PEG)Treated Hydroponic Culture Reduces Length and Diameter of Root Hairs of Wheat Varieties. Agronomy 2015, 5: 506-518.

Sarlach R.S., S.A and Bains N.S. (2013)Seed priming in wheat:Effect on seed germination, yield parameters and grain yield. Society for Sci. Dev. in Agric. and Tech, 2016;8(1): 109-112.

Toklu F. and Baloch F. S. (2015), Effects of different priming applications on seed germination and some agromorphological characteristics of bread wheat (Triticum aestivum L.).Turk $J$ Agric., (2015); 39: 1005-1013.

\section{How to cite this article:}

Tabom Tatak, Rajesh Singh and Punnam Chhetri. 2021. Effect of Seed Hardening and Irrigation on Growth and Yield of Wheat (Triticum aestivum L.). Int.J.Curr.Microbiol.App.Sci. 10(02): 418-423. doi: https://doi.org/10.20546/ijcmas.2021.1002.049 